\title{
FURTHER THOUGHTS ON EMPLOYMENT DISCRIMINATION LEGISLATION: A REPLY TO JUDGE POSNER
}

\author{
John J. Donohue III $\dagger$
}

I have profited greatly from reading Judge Posner's review ${ }^{1}$ of my initial Essay, Is Title VII Efficient? ${ }^{2}$ As usual, he has raised a number of thought-provoking issues that must be addressed if we are to make headway in resolving the difficult theoretical and empirical issues posed by employment discrimination legislation. In Part I of this reply, I will discuss Judge Posner's specific criticisms of my theoretical analysis and then discuss the results of a very rough cost-benefit analysis of Title $\mathrm{VII}^{3}$ that incorporates Judge Posner's concerns. The details of the costbenefit analysis are supplied in an Appendix. Part II will then offer some preliminary thoughts on Judge Posner's empirical assessment of Title VII.

\section{The Critique of My Theoretical Analysis}

My Essay examined the Beckerian argument ${ }^{4}$ that, in a world in which discrimination against minorities is based on animus, we do not need, nor do we profit from having, legislation that prohibits discrimination. This view is based on the theoretical conclusion that, in the short run, the interference with competitive labor markets caused by antidiscrimination legislation is harmful, and, in the long run, it is unnecessary because discriminators will go the way of all nonprofit maximizers-out of business. My Essay questioned this "efficiency attack" on Title VII by showing that, while antidiscrimination legislation may

† Assistant Professor of Law, Northwestern University; Research Fellow, American Bar Foundation. B.A. 1974, Hamilton College; J.D. 1977, Harvard Law School; M.A. 1982, M.Phil. 1984, Ph.D. (economics) 1986, Yale University. I would like to thank Ronald Allen, Joseph Altonji, Ian Ayres, William Felstiner, Herbert Kritzer, Judge Richard Posner, Peter Siegelman, and David Van Zandt for their helpful comments.

1 Posner, The Efficiency and Efficacy of Title VII, 136 U. PA. L. REv. 517 (1987).

${ }^{2}$ Donohue, Is Title VII Efficient?, 134 U. PA. L. REv. 1411 (1986). (1982).

Title VII of the Civil Rights Act of 1964, 42 U.S.C. $\$ \S 2000(e)-2000(e)(17)$

See Donohue, supra note 2, at 1415-20 (discussing G. BECKER, The Economics of Discrimination (2d ed. 1971)). 
be inefficient in the short run, it does have an offsetting advantage: it will tend to eliminate discriminators more quickly than the free market would. I take it that Judge Posner does not dispute my theoretical demonstration of this proposition. He does question, however, whether it is economically efficient to speed up the process of achieving a discrimination-free labor market. ${ }^{\S}$

\section{A. Will Title VII End Discrimination Too Quickly?}

While Judge Posner would certainly agree that we are better off if employers who harbor racial animus are squeezed out of the market, he offers two reasons for believing that the cost of moving to this happy condition through government intervention may be too great. In essence, Judge Posner argues that my assessment of the efficiency of Title VII would be altered if I explicitly considered the costs of administering the Act and the added costs of adjustment that it imposes in driving discriminators from the market more quickly than would occur under laissez faire. ${ }^{6}$ Subsections (1) and (2) will discuss each of these factors. I will then try to incorporate them in a very rough cost-benefit analysis of the Act, which I discuss in Part I (B).

\section{The Costs of Administering Title VII}

In Figure 3 of my Essay, ${ }^{7}$ I demonstrated that Title VII would reduce wealth initially from $\mathrm{SW}_{2}$ to $\mathrm{SW}_{3}$ because the Act interfered with employer preferences. In the long run, however, the Act would generate the benefit of elevating welfare to $\mathrm{SW}_{1}$ more quickly, since discriminators would be driven from the market more rapidly. I then concluded that, if the long-run benefits (b) exceeded the short-run costs (a), the Act was efficient. ${ }^{8}$ Judge Posner quite correctly notes, however, that administering Title VII is costly. ${ }^{9} \mathrm{My}$ rough estimate of these costs is $\$ 300$ million per year based on 6000 suits alleging racial discrimination in employment.

- See Posner, supra note 1, at 518.

Id. at 518-20.

7 Donohue, supra note 2, at 1424.

8 Id. at 1427.

- Posner, supra note 1, at 518. 
Figure 3

The Time Path of Social Welfare With and Without Title VII

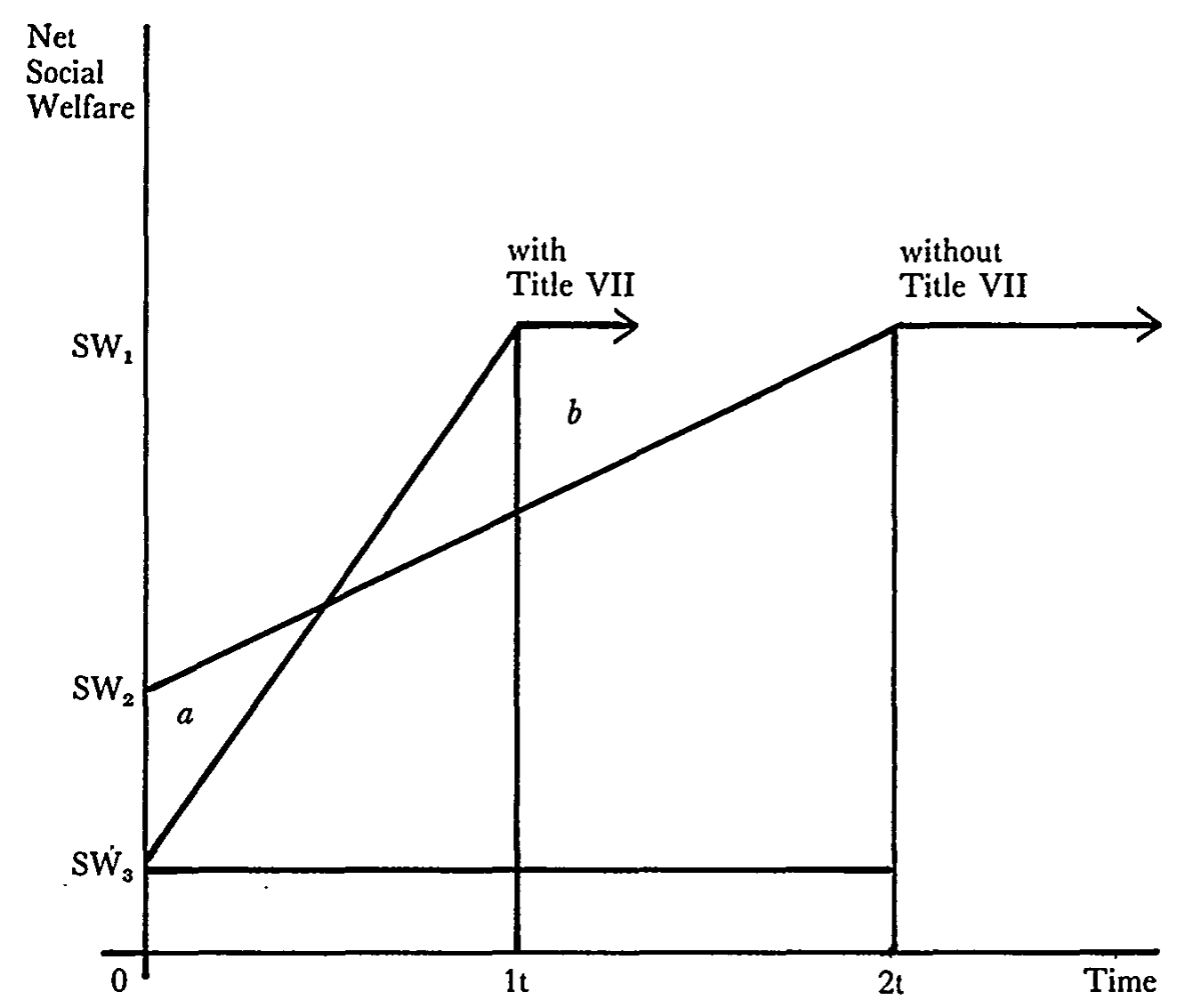

\section{The Added Costs of Adjustment Under Title VII}

Judge Posner's second point is, as he notes, more subtle. Adhering to Becker's analogy that discrimination can be thought of as similar to the transportation costs that deter nations from engaging in international trade, Judge Posner contends that a law forbidding discrimination would be as ill-advised as a law requiring two nations to engage in trade when the transportation costs between them made such trade inefficient. ${ }^{10}$ But this analogy is flawed. In Judge Posner's international trade example, the level of trade is assumed to be at some equilibrium level based on the existing size of transportation costs. Unless these costs changed, there would be no economic force that would induce changes in the level of international trade, nor would there be any advantage in the government trying to depart from this equilibrium con-

${ }^{10}$ Id. at 519. 
dition. In the Beckerian world, however, discrimination is a disequilibrium phenomenon: over time, discriminators would be driven from the market because they failed to minimize costs. ${ }^{11}$ In this case, government intervention is potentially useful because it can speed up this process.

Judge Posner next analogizes Title VII to a law requiring the international maritime industry to adopt a new and more efficient technology. ${ }^{12}$ This is a more appropriate analogy because, by assumption, the new technology will ultimately replace the old technology just as nondiscriminators will ultimately replace discriminators. Judge Posner properly questions whether the government would do a better job than business enterprises at determining the optimal rate at which the new technology should supplant the old. While I think the analogy is useful to illustrate Judge Posner's point-that is, that with frictionless competitive markets even the speed at which the economy moves towards a new equilibrium will be optimal-there are important distinctions between a law that tries to encourage a new transportation technology and one that tries to eradicate discrimination in employment.

For example, assume that all trans-Atlantic shipping is being carried by boat when the invention of the cargo plane provides a lower cost method of shipping. Ultimately, all trans-Atlantic shipments will be by plane. This does not mean that we should immediately scrap the existing boats, which may have no other use than for ocean freight transportation. Since the boats have already been built, they represent "sunk" costs. ${ }^{13}$ As a result, the variable cost of continuing to use the boats may be less than the full cost of using a plane to carry the cargo. In this case, the boats will be used until they wear out, and the proportion of freight sent by air will constantly expand. A law that taxed the use of the old boats would generate a quicker conversion to plane cargoes but at the cost of wasting valuable resources.

Similarly, Judge Posner argues that the market, rather than the government, should determine the rate at which discriminators are eliminated, noting that adjustment costs are higher if the process occurs too quickly. ${ }^{14}$ But we have already noted that the case of employment discrimination is unlike the case of an old technology that should not necessarily be immediately scrapped if it still retains sufficient value. The reason is that a company that owns outmoded machines cannot suddenly be transformed into an efficient operation by simply transfer-

\footnotetext{
11 Donohue, supra note 2, at 1426-27.

12 Posner, supra note 1, at 519.

13 This is not a pun, but an economic concept.

14 Posner, supra note 1 , at 518.
} 
ring the assets to another party. But this is precisely the case for a discriminatory firm: if a nondiscriminator buys out a discriminator, the psychic costs of discrimination immediately disappear. Therefore, an upper bound estimate of the cost needed to eliminate employer discrimination is simply the cost of transferring the assets to nondiscriminators. ${ }^{16}$ But the Becker model tells us that this transfer will take place ultimately even without Title VII. ${ }^{16}$ Indeed, the assurance that the discriminators will be eradicated absent legislation is one of the strongest arguments against Title VII, so the costs of adjustment associated with driving discriminators out of the market will presumably be faced whether the Act is passed or not. Consequently, the only additional burden imposed by the Act results from the fact that these adjustment costs are borne earlier-and are thus larger in present value terms-under Title VII.

To summarize: merely transferring ownership to a nondiscriminator automatically yields an immediate benefit since the psychic costs of discrimination would thereby be eliminated. ${ }^{17}$ Moreover, while there are no sunk costs to consider in the case of discrimination, there are transaction costs incurred in transferring ownership. But, Judge Posner can be heard to say, if there are immediate benefits to be had at little cost, one would expect the market to generate these benefits. Clearly, if every employer were ruthlessly maximizing profits, then we would not need Title VII because there would be no animus-based discrimination in the first place. If there are enough enterprising individuals who either exploit the possibility of hiring cheap black labor or who simply buy out discriminatory firms, then there still may be no role for the government, for in this event the path to the new equilibrium will indeed be optimal. In essence, at every point in time these actors would be calculating whether the benefits from undermining a discriminator are sufficient to justify the costs of such competition. If the costs are too great, it would not be efficient for government to encourage this behav-

15 It is costly to transfer resources from discriminators to nondiscriminators because lawyers, bankers, and company officials must be drawn from some other activity to effect such a change. This is an upper bound estimate, since other responses to the Act that would yield the same result of eliminating discrimination would presumably be rejected if they were more costly, and might be accepted if they were less expensive.

${ }_{18}$ See G. BECKER, supra note 4, at 39-47; R. POSNER, ECONOMIC ANALYSIS OF LAw § 27.1 (3d ed. 1986).

${ }_{17}$ We know that a nondiscriminator can earn a higher rate of return on his business than a discriminator since the latter is burdened with the psychic costs of having to associate with workers he dislikes. Therefore, if the discriminatory owner sells his business to a nondiscriminator, then both parties can be made better off. The psychic costs act as a type of "bribe" that encourages the sale. See J. Donohue, Diverting the Coasean River: Incentive Schemes to Reduce Unemployment Spells 11-13 (Sept. 1987) (unpublished manuscript) (on file with the University of Pennsylvania Law Review). 
ior. If the benefits exceed the costs at any given moment, the discriminators should be flushed from the system by the operation of market forces.

But why doesn't the process occur more quickly? Perhaps the answer lies in the fact that some types of departures from profit-maximization are punished far less quickly and thoroughly than we might have thought. ${ }^{18}$ As long as there is some rigidity in the market, there is no reason to believe that the market will generate the optimal path to the nondiscriminatory equilibrium. ${ }^{19}$ And, as Kenneth Arrow has noted, the persistence of discrimination for decades suggests that either Becker's model is wrong in predicting the demise of employer discrimination, or there is some rigidity in the market that may justify government intervention. ${ }^{20}$ Consequently, it may be useful to undertake a simple cost-benefit analysis in order to get some sense of whether Title VII might indeed be efficient and which factors influence this determination. The details of this analysis, which necessarily involves a number of highly speculative assumptions, are set forth in the Appendix. Section $B$ summarizes the results.

\section{B. The Results of A Simple Cost-Benefit Analysis}

The major economic benefit, $b$, provided by Title VII is that it more rapidly eliminates discriminators from the market, thereby eliminating the large psychic costs of discrimination. At the same time, there are three offsetting costs to be considered: 1) the short-run efficiency loss associated with interfering with the preferences of discriminatory employers, $a$; 2) the administration costs of the Act, $c$; and 3) the adjustment costs associated with driving discriminators from the market, $d$.

The main conclusions reached with respect to these quantities are as follows:

1. I assume that initially there are 50,000 discriminatory firms. The passage of the Act precipitates the elimination of 5000 firms in the

18 See R. Nelson \& S. Winter, An Evolutionary Theory of Economic Change 139-54 (1982); Akerlof \& Yellen, Can Small Deviations From Rationality Make Significant Differences to Economic Equilibria?, 75 AM. Econ. REv. 708 (1985).

18 Donald Parsons has demonstrated that, in the wake of a shock to one sector that causes a decline in product demand and a concomitant reduction in labor employed in that sector, government intervention may provide a superior path to the new equilibrium if intersectoral wage adjustments are slow. Parsons, Unemployment, the Allocation of Labor, and Optimal Government Intervention, 70 AM. ECON. REv. 626, 62733 (1980).

20 See Donohue, supra note 2, at 1422 n.31. 
first year and 2500 firms in the second year that would have remained in business for ten years in the laissez-faire state. At the same time, there is an immediate increase in the wages of black labor by $5 \%$, and approximately 268,700 additional blacks are hired. ${ }^{21}$ The initial wave eliminating 5000 firms generates annual benefits of $\$ 578$ million for the next ten years, at which time it is assumed that the firms would have been driven out of the market by the normal competitive pressures on discriminators. Assuming a $10 \%$ real interest rate, this stream of benefits has a net present value of $\$ 3550$ million. ${ }^{22}$ The second wave generates benefits of half that size. Therefore, total benefits, $b$, have a present value of $\$ 5165$ million.

2. The dead weight efficiency loss, $a$, represents the psychic losses imposed on discriminators by forcing them to hire more blacks than they otherwise would. In the first year, this cost equals $\$ 208.9$ million, although as discriminators are driven from the market, the cost will decline towards zero. ${ }^{23}$ Assuming that it falls to zero in twenty years, the present value of this cost is $\$ 1200$ million.

3. The annual administration costs, $c$, imposed by the Act are assumed to be $\$ 300$ million per year initially. The present value of this cost is $\$ 1723$ million if the initial $\$ 300$ million cost declines to zero in twenty years as discriminators are forced out of the market, and $\$ 3000$ million if the costs continue forever.

4. The cost of adjustment, $d$, is the cost associated with discriminators being forced out of the market, whether by the Act or competition. Although these expenses are assumed to be the same regardless of which force drives out the discriminator, they are assumed to occur ten years earlier under the Act. With 5000 firms driven out in the first year and a per-firm adjustment cost of $\$ 200,000, d$ equals $\$ 1$ billion. Since these firms would ultimately have been driven out owing to normal competitive pressures, the only cost added by the Act is that this $\$ 1$ billion is incurred immediately rather than in ten years. Thus, the present value of this cost is $\$ 614$ million. Adding in the costs associated with the 2500 second-year exits leaves a total adjustment cost of $\$ 894$

21 Although this analysis can easily be generalized to all forms of employment discrimination, both Judge Posner and I have focused our discussion on racial discrimination.

${ }^{22}$ The official discount rate employed by the Office of Management and Budget in evaluating governmental programs has been $10 \%$ since 1972. See Office of Management \& Budget, Executive Office of the President, Circular No. A-94 revised (March 27, 1972) (George P. Schultz, Director).

23 While the case that I am discussing involves $15 \%$ of the initial discriminators being driven from the market by the Act in the first two years, I assume that normal competitive forces will drive out the remaining $85 \%$ by the end of 20 years. 


\section{million. ${ }^{24}$}

Consideration of the above four factors yields the following results. Against the Act's benefits of $\$ 5165$ million are arrayed the adjustment costs of $\$ 894$ million and the total future efficiency losses of $\$ 1200$ million and the total future administration costs of $\$ 1723$ million. This yields a net benefit of $\$ 1349$ million as indicated in row 1 of Table 1 .

Table 1

NET BENEFITS OF TITLE VII UNDER VARIOUS ASSUMPTIONS (in Millions)

Number of Discriminators Driven Out By The Act NONE $^{25} \quad 10 \%{ }^{28} \quad 1$ ST YR $-10 \%{ }^{27} \quad$ ALL $^{28}$ 2ND YR-5\%

Administration Costs

Fall to Zero in Year 20

14

Adding Net Effect

of Statistical

Discrimination

1263

With No Human Capital

Effect From Statistical

Discrimination

$-3157 \quad-220$

1115

5503

Administration Costs

Continue Forever

$-4200-1263$

72

4460

Adding Net Effect

of Statistical

Discrimination

$-4286-1349$

$-14$

4374

With No Human Capital

Effect From Statistical

Discrimination

$-4434 \quad-1497$

$-162$

4226

24 Note that if additional firms were driven out by the Act in the third year and beyond, then the estimated net benefits of the Act would have increased, since the benefits for each succeeding year would exceed the accompanying adjustment costs.

${ }^{25}$ All discriminators will be driven from the market in 20 years with or without Title VII.

${ }^{28}$ Ten percent of discriminators driven out in first year that would on average have remained in business for 10 years without the Act. Thereafter, no more discriminators are driven out by the Act, although the market drives out the remaining discriminators in 20 years.

${ }^{27}$ Same as in column two, see supra note 26 , with an additional $5 \%$ driven out by the Act in the second year.

${ }^{28}$ Five percent of the initial discriminators are driven out each year under Title VII, while without the Act, the corresponding yearly figure is $2.5 \%$. Thus, Title VII eliminates all discriminators in 20 years, while the same result would take 40 years 
Table 1 demonstrates the effect of different assumptions concerning the number of firms driven from the market. The scenario discussed above involved the assumption that $10 \%$ of the discriminators were driven from the market in the year following passage of Title VII and another $5 \%$ followed in the second year. If no additional firms were driven out in the second year, the net benefit of the Act would fall to $\$ 14$ million. On the other hand, if all discriminators were driven out in 20 years, while without Title VII this result would take 40 years, the benefits of the Act would rise to $\$ 5737$ million. Of course, if no discriminators are driven out, there are no benefits in the model, and therefore the Act is necessarily inefficient.

Table I also illustrates that assumptions about the continuation of administration costs are important to an assessment of the efficiency of the Act. Presumably, as discriminators are driven from the market, the number of suits will decline. On the other hand, some of the administration costs involve the costs associated with frivolous suits or engaging in cosmetic changes to avoid litigation. Such costs might continue forever. I therefore bracket the options by assuming in the first row that the $\$ 300$ million yearly administration costs decline to zero in twenty years, and in the fourth row that they continue at this level forever. This change causes the net benefits of the Act to fall from $\$ 1349$ million to $\$ 72$ million, when the Act succeeds in driving out discriminators in the first two years. If, however, no additional discriminators are eliminated by the Act in the second or succeeding years, and if the administration costs continue forever, then the net benefits of the Act fall from $\$ 14$ million to $-\$ 1263$ million. This figure represents a onetime expense of roughly $\$ 5$ for every American. ${ }^{2 \theta}$

\section{Is It Inefficient to Prohibit Statistical Discrimination?}

In my original Essay and thus far in the present Essay, I have followed Becker in explicitly assuming that discrimination is caused by employers' animus against the disfavored minority. ${ }^{30}$ Many analysts have found this model appealing and have emphasized its prediction that the free market will eliminate discriminatory employers. ${ }^{31}$ In his

without the Act.

${ }^{29}$ To put this expense in perspective, $\$ 1263$ million was roughly twice the size of the loss that RCA incurred in three years on its ill-fated VideoDisc venture. See M. Graham, RCA and the VideoDisc: The Business of Research 213 (1986) (total loss to RCA was about $\$ 580$ million).

so See Donohue, supra note 2, at 1415-20.

31 See M. Friedman, Capitalism and Freedom 108-115 (1962) (market forces are more effective than government programs in eliminating discrimination); R. PosNER, supra note $16, \S 27.1$ (discrimination more likely in regulated than in unregu- 
rebuttal to my Essay, however, Judge Posner raises the possibility that employment discrimination could have a different genesis, in which the disciplinary role of the market as the ally of the victims of discrimination is absent. He notes that "a reluctance by employers to employ blacks at the same wage as whites" may be the product of "statistical discrimination," in which discrimination against, for example, blacks is not the result of racial animus, but rather stems from a realization that, for whatever reasons, black workers are on average less productive than white workers. ${ }^{32}$ If this generalization is accurate, and if it is costly to ascertain individual abilities, then statistical discrimination, unlike Beckerian discrimination, may be profit-maximizing.

Since statistical discrimination can be profit-maximizing, it tends to be stable while Beckerian discrimination tends to be eroded by competitive markets. Consequently, if we are dealing with a case of statistical rather than Beckerian discrimination, then the effect of Title VII is indeed different from that presented in my initial Essay. Nonetheless, the conclusion that I reached with respect to animus-based discrimination may also apply in the case of statistical discrimination: specifically, while prohibiting employers from discriminating may be inefficient in the short run, it may be efficient in the long run.

While at least one noted authority has questioned whether statistical discrimination is a convincing explanation for the large black-white earnings differentials ${ }^{33}$ the model assumes that employers discriminate against blacks because knowledge of race conveys useful information. Even though employers realize that such generalizations are not universally true, it may still be profitable for firms to act as if they were rather than to expend resources to determine which blacks have higher than average productivity or which whites have lower than average productivity. At first glance, it might seem that statistical discrimination will necessarily be efficient whenever it is profit-maximizing. Nonetheless, it is possible that discrimination could be profit-maximizing for the firm, yet inefficient for society as a whole.

The basic argument is that statistical discrimination will distort the incentives for individuals to invest in human capital since they will simply be treated as the average member of their class whether or not they make such investments. By divorcing an employee's individual

lated markets); T. SOWELl, MARKETS AND MinoRITIES 34-51 (1981) (interferences with a competitive market can cause distortions in the market's tendency to reward nondiscriminatory employers).

32 Posner, supra note 1 , at 520.

ss Cain, The Economic Analysis of Labor Market Discrimination: A Survey, in 1 HANDBOOK OF LABOR ECONOMICS 729 (1986). 
productivity from the wage that the employee receives, statistical discrimination introduces inefficiencies into the human capital investment decisions of workers. If the concomitant costs are large, statistical discrimination may be harmful from a social perspective, although beneficial to individual employers. ${ }^{34}$ By discouraging workers from investing in their own human capital, society is deprived of all of the benefits that flow from these investments. ${ }^{35}$ Therefore, while we should recognize that, unlike animus-based discrimination, statistical discrimination is presumably profit-maximizing, a full cost-benefit analysis of Title VII would include the benefits from proscribing statistical discrimination as well as the costs. ${ }^{36}$ Indeed, in estimating the added costs from prohibiting statistical discrimination in Section B of the Appendix, it seems a distinct possibility that the prohibition enlarges the previously estimated net benefits of the Act. Moreover, even if statistical discrimination did not distort the incentive of workers, ${ }^{37}$ the costs imposed by prohibiting it $-\$ 234$ million-are smaller than the estimated net benefits of the Act of $\$ 1349$ million. $^{38}$

My simple cost-benefit analysis is based on the assumption that Title VII succeeded in increasing the wages and employment level of black workers. I think this certainly would have been a reasonable assumption for the authors of the Act back in 1964. From the perspective of 1987, though, Judge Posner contends that the benefits that might

${ }^{34}$ See Lundberg \& Startz, Private Discrimination and Social Intervention in Competitive Labor Markets, 73 Am. Econ. REv. 340, 346-47 (1986); Schwab, Is Statistical Discrimination Efficient?, 76 AM. EcoN. Rev. 228, 233 (1983).

35 Indeed, the Heckman piece cited by Judge Posner stresses the importance of human capital investments in improving the economic status of blacks. As Heckman notes, "The evidence on the importance of training and education on determining black economic status is more favorable than many would have it." J. Heckman, The Impact of Government on the Economic Status of Black Americans 22 (rev. May 1987) (unpublished manuscript) (on file with the University of Pennsylvania Law Review).

s6 I think Judge Posner would concede that if statistical discrimination could be prevented, the income of blacks would be enhanced. This might also generate efficiencies, since anything that enhances the wealth of the poor can yield efficiency gains by providing for more efficient means of social control. Donohue \& Ayres, Posner's Symphony No. 3: Thinking About the Unthinkable, 39 StaN. L. REv. 791, 801 (1987).

${ }^{37}$ Even if when viewed in isolation the costs from prohibiting statistical discrimination appeared to exceed the benefits, there may still be a basis for prohibiting it on efficiency grounds. This might be the case if allowing statistical discrimination defenses by employers substantially increased the Type 2 error in Title VII cases alleging animus-based discrimination. See generally R. Hogg \& E. TANis, Probability and Statistical Inferences 254 (1977) (discussing and distinguishing Type 1 and Type 2 errors).

${ }^{38}$ On the other hand, if the Act only provides benefits in the first year by knocking out $10 \%$ of discriminators, then the benefits of Title VII become negative when the effect of prohibiting statistical discrimination is included. 
have been predicted to flow from Title VII simply have not emerged. ${ }^{39}$ It is to this issue that I now turn.

\section{Has Title VII Improved the Economic Progress of BLACKS?}

Judge Posner suggests that, regardless of what economic theory might predict about the consequences of efforts to stimulate demand for black labor by eliminating labor market discrimination, the empirical evidence concerning the impact of Title VII is inconclusive. ${ }^{40}$ Whether this is because the Act's benefits, if any, have been modest or because, as Judge Posner himself notes, it is exceptionally difficult to untangle the effects of Title VII on black economic progress when so many other factors are occurring simultaneously, is of course a crucial question. Where one places the burden of persuasion may well resolve the controversy given the empirical uncertainties.

It is worth noting that my rough cost-benefit analysis suggesting that Title VII was efficient was based on the assumption that the passage of the Act would elevate black wages by $5 \%$. Given the tremendous demographic changes that the economy was undergoing in the late $60 \mathrm{~s}$ and the $70 \mathrm{~s}$, it is perhaps not surprising that an increase of this relatively modest proportion would not emerge clearly from aggregate United States data. For example, at the same time that Title VII might have been providing a demand stimulus for blacks, the increased labor force participation of women may have been dampening black wage increases through a large supply effect. The very interesting and recent empirical evidence presented by Judge Posner to dispute the claimed benefits of Title VII must be evaluated in this light.

Perhaps a brief discussion of some of the literature dealing with the effect of Title VII would be useful. A number of analysts have noted that the economic position of blacks appeared to improve after 1964. In 1973, Richard Freeman characterized these gains as "dramatic," signalling a "virtual collapse in traditional discriminatory patterns." "11 Richard Butler and James Heckman questioned this conclusion a few years later. Their basic thesis was that, after 1964, the least productive blacks tended to leave the labor market, thereby creating the illusion in the comparative black/white income data that blacks had

39 See Posner, supra note 1, at 524.

10 See id. at 524.

11 Freeman, The Changing Labor Market for Black Americans 1948-72, in 1 Brookings Papers on ECONOMIC ACTIVITY 67, 67 (1973). 
experienced economic progress. ${ }^{42}$

When Freeman revisited the issue in 1981, he had clearly become more guarded in his conclusions about the extent of black progress. Nonetheless, he concluded that the supply-side effect that Butler and Heckman had identified was not a significant factor in explaining the statistical appearance of black progress. In fact, Freeman contended that Butler and Heckman had "inadvertently used data with several keypunch errors," which, when corrected, undermined their supplyside explanation. ${ }^{33}$ After a very careful analysis of the data, Freeman concluded as follows:

In sum, while by no means definitive, or ruling out other factors, the evidence on timing, on incidence, and on company personnel and employment practices suggests that at least some of the post-1964 black gains resulted from increases in demand for black labor induced, at least in part, by programs designed to accomplish that purpose. Imperfect though it is, the evidence indicates that the national antibias effort has contributed to black economic progress. As far as can be told from the data, if Title VII were repealed and equal employment efforts ended, the rate of black advancement would fall. ${ }^{44}$

I am grateful to Judge Posner for bringing to my attention Heckman's latest work in this area. ${ }^{45}$ This brief article conveys the very important message that it is unwise to rely uncritically on much of the data introduced into popular discussions of public policy issues. For example, Heckman persuades me that a considerable amount of the ostensible progress in narrowing black/white wage differentials is the result of a disproportionate tendency on the part of low-earning blacks to drop out of the labor force and of problems in the official earnings statistics that understate the earnings of (predominantly white) members of high-income occupations and disproportionately fail to interview poor blacks. ${ }^{48}$

While Heckman states, however, that "very little reliable information is available about negative or positive effects of affirmative action

12 See Butler \& Heckman, Government's Impact on the Labor Market Status of Black Americans: A Critical Review, in Industrial RELATIONS RESEARCH AssociaTION, EQUAL Rights aNd INDUSTRIAL Relations 235, 235, 265-67 (1977).

4s Freeman, Black Economic Progress After 1964: Who Has Gained and Why?, in StUdies IN LABOR MARKeTS 247, 291 n.26 (1981).

14 Id. at 283.

$45 \mathrm{~J}$. Heckman, supra note 35.

18 See id. at 11-13. 
programs and equal rights programs on the status of blacks in the aggregate, ${ }^{\prime 47}$ he is more forceful in drawing conclusions based on his own research conducted with Brook Payner on the South Carolina labor market. ${ }^{48}$ Heckman notes that the share of black employment in the South Carolina textile industry was less than 10\% before 1965-the year that Title VII became operative--but by 1970 , the industry was roughly $30 \%$ black. $^{49}$ Heckman and Payner found that

the breakthrough in black employment in the state occurred shortly after the implementation of Title VII civil rights legislation. The highly synchronized breakthrough in black employment that occurred in all counties of the state irrespective of the tightness or slackness of county local labor markets and the available supply of blacks suggests a common factor was present in all counties-federal pressure. ${ }^{50}$

Moreover, Heckman's conclusion on the South Carolina experience is consistent with the basic message of my own Essay. He writes that "the black breakthrough occurred at a time when the South Carolina and national economies were generally tight and that federal civil rights activity may have primarily played a facilitating role for a breakthrough that underlying economic forces might have produced in any event." This is precisely the point that my Essay tried to emphasize: Title VII can speed up the arrival at the ultimate nondiscriminatory equilibrium. I am reluctant to dismiss the effectiveness of antidiscrimination legislation in light of the experience in South Garolina suggesting that the effects of Title VII were much as theory would predict.

Judge Posner offers two reasons why Title VII may not be effective in practice. First, he argues that, because of the nature of proof in Title VII cases, employers have responded to the Act as if it mandated a higher minimum wage for blacks than the market would establish. ${ }^{\mathbf{5 2}}$ As a result, there are winners and losers in the process, and, on the whole, the gains and losses cancel each other out. I conceded this possibility in my original Essay. ${ }^{53}$ On the other hand, the purpose of Title VII is to provide greater protection for black workers than a mere equal pay act, and if in practice Title VII has not been implemented in this way, perhaps a greater commitment towards, rather than a willing-

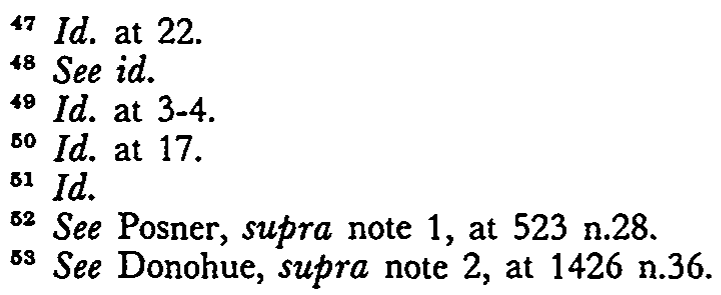


ness to dispense with, Title VII would be appropriate. ${ }^{54}$ Furthermore, even if discriminators avoid full compliance with Title VII by treating it only as an equal pay act, they will still be worse off with such an act than they would be under laissez faire. Therefore, in accordance with the mechanism I described in my initial Essay, Title VII should still hasten the elimination of these discriminators from the market, thereby generating the attendant benefits.

Second, Judge Posner contends that Title VII may not increase the demand for black labor since employers will realize that blacks may end up suing them for employment discrimination. ${ }^{55}$ On this view, rather than stimulating demand for black labor, Title VII acts as a tax on black labor that harms the economic prospects of blacks. While Judge Posner is correct in identifying this cost, I suspect it is quite small in comparison with the offsetting stimulus to the hiring of black workers, since a failure to hire blacks will definitely increase the probability of a Title VII lawsuit. Thus, one might say that there is a small tax associated with hiring blacks because they may someday sue the employer if fired or not promoted, but a large tax associated with failing to hire blacks because of the increased likelihood that they will sue. The net effect would seem to be a demand stimulus.

Judge Posner might reply, however, that the employer may be able to avoid both taxes by simply relocating in states with virtually no minority populations. This possibility underscores the difficulty in trying to restrain market preferences through legal regimes. Nonetheless, my guess is that the incentive to avoid the small tax is too modest to provide a substantial impetus for firms to move to locations with small minority populations. I have estimated that the annual administration costs associated with the Act are roughly $\$ 300$ million. Perhaps half of this cost falls on private employers, the rest falling on taxpayers and plaintiffs. If we assume that each year 2000 plaintiffs receive backpay awards of $\$ 10$ thousand-which seems quite high-then the total of the awards generated by these cases is $\$ 20$ million. ${ }^{56}$ In addition, I assume that 12,000 cases are settled, before a federal suit is filed, at an average settlement of $\$ 1000$ per case, or $\$ 12$ million in total. Combining the potential administration burden of $\$ 150$ million with the potential trial and settlement losses of $\$ 32$ million yields a total potential liability of

54 I demonstrated in my original Essay how an equal pay act might decrease black employment from the level of employment in a discriminatory laissez-faire state. See id. Title VII was designed to increase both the black employment level and black wages by mandating the attainment of the nondiscriminatory equilibrium.

so See Posner, supra note 1 , at 524 .

${ }^{58}$ I have estimated the annual number of suits alleging racial bias in employment to be 6000 . 
$\$ 182$ million. Consequently, the expected "small tax" from hiring one of the 10.7 million black workers is about $\$ 17$ per year. I doubt that amount is sufficient to cause many significant relocations. Moreover, if this factor had an important influence on regional growth, one would expect that, in the wake of Title VII, regions with high numbers of blacks such as the South would have stagnated. ${ }^{57}$ But, rather than stagnating, the South has experienced an "economic revolution," which is all the more dramatic given the fact that "as recently as twenty-five years ago, regional economic backwardness in the states of the traditional American South was considered an intractable problem of continuing national concern."

\section{ConCLUSION}

Limits of time and space prevent me from addressing a number of issues germane to the debate over Title VII, but I should mention two additional points in passing. First, in this Essay, I have tried to assess the factors that influence the question of the efficiency of Title VII while giving full weight to the preferences of all individuals. The resulting cost-benefit analysis-although based upon a large number of necessarily arbitrary assumptions-provides tentative support for the conclusion that either Title VII is efficient, or at least not as costly as Judge Posner may have feared. Some might contend, however, that in analyzing Title VII, we should simply refuse to recognize the psychic costs imposed on discriminators when they associate with black workers. In that case, the nondiscriminatory outcome that Title VII seeks to impose is by definition optimal, and the only remaining questions are whether the Act can move us toward that outcome and at what cost. This approach necessarily strengthens the case for Title VII.

Second, there is also a strong argument to be made that Title VII has been part of a much larger governmental effort undertaken in the United States since World War II to decrease racial prejudice. This effort includes President Truman's actions in integrating the armed forces in the 1940s, the Brown v. Board of Education ${ }^{58}$ decision requiring the desegregation of schools in the 1950s, and the passage of state equal employment opportunity laws prior to the enactment of $\mathrm{Ti}$ -

87 While in 1980 blacks made up $11.69 \%$ of the total U.S. population, they comprised $18.63 \%$ of the Southern population-a figure almost twice the size of the proportion of blacks in any other primary census region. U.S. BUREAU OF THE GENSUS, United States Dep'T of Commerce, 1983 County and Gity Data Book 2. (1987).

s8 Wright, The Economic Revolution in the American South, 1 ECON. PERSP. 161

s9 347 U.S. 483 (1954). 
tle VII in $1964 .^{60}$ In a complex interactive process, these governmental acts were hastened by and encouraged the decline in discriminatory attitudes that has occurred since World War II. ${ }^{61}$ Of course, any incremental role played by Title VII in stimulating this attitudinal change would yield additional benefits-similar to technological advances in the transportation realm, to use Judge Posner's analogy-in reducing the psychic costs of discrimination. ${ }^{62}$

Finally, the primary assumptions upon which the conclusion of Title VII's efficiency depends are that 1 ) increased demand causes the wages of black workers to rise 5\%; and 2) substantial numbers of discriminators are driven from the market earlier than they would have been without Title VII. If these conditions hold, then the Act generates substantial benefits that in all likelihood far exceed its costs. Interestingly, while Judge Posner has emphasized his doubts that Title VII has been effective in aiding blacks, my cost-benefit analysis has shown that relatively modest gains for blacks yield very large efficiency gains if simultaneously the Act forces discriminators from the market. Since $5 \%$ is such a modest wage hike, I am fairly confident that this condition has been met. Nonetheless, while I have tried to use Becker's model of discrimination to suggest that the Act will in fact eliminate discriminators, I am much less certain whether this prediction of theory has been borne out in reality. Of course, if the relatively more forceful economic pressures exerted by Title VII have failed to discipline discriminators, we may well have to rethink the view that market pressures under laissez faire will succeed in doing so. ${ }^{63}$

Accordingly, there is much that we still do not know about the consequences of enacting Title VII. I hope my original Essay and the

${ }^{60}$ Almost all the states in the Pacific, mid-Atlantic, and east north central regions of the country had adopted equal employment acts prior to 1964. See P. BurSTEIN, Discrimination, Jobs, and Politics 52 (1985).

61 Paul Burstein presents evidence on the continual increase in the numbers of individuals who consider blacks to be equal to whites. See id. at 141.

${ }_{62}$ The power of law to influence attitudes is captured succinctly in the comment of Sir James Fitzjames Stephen in 1863:

Some men, probably, abstain from murder because they fear that if they committed murder they would be hanged. Hundreds of thousands abstain from it because they regard it with horror. One great reason why they regard it with horror is that murderers are hanged with the hearty approbation of all reasonable men.

J. Stephen, A General View of the Griminal Law of England 99 (1863) quoted in J. ANDEnaEs, Punishment AND Deterrence 21 (1974).

${ }^{63}$ An alternative position is that both Title VII and the market are capable of forcing discriminators to act in a nondiscriminatory fashion, but are not able to drive them from the market. While there may well be merit to this view, it is inconsistent with the Beckerian and Posnerian notions that the psychic costs of discrimination are exactly analogous to other economic costs such as transportation costs. 
dialogue it has spawned have helped clarify some of the relevant issues so that future research can provide more precise answers to these questions.

\section{Appendix: A Simple Cost-Benefits Analysis of Title VII}

Both my Essay and Judge Posner's response have emphasized that there are a number of costs and benefits associated with the enactment of Title VII. In this Appendix, I would like to try to provide some very rough estimates concerning the size of these various costs and benefits in order to ascertain whether any tentative conclusion can be drawn concerning the efficiency of the Act, and also to shed light on the factors that influence this determination. This endeavor necessarily requires me to make a number of highly speculative assumptions and estimates, which I will try to state explicitly so that others may question or vary them as they see fit.

\section{A. Animus-Based Discrimination}

While Section B of this Appendix extends my analysis to include the case of "statistical discrimination," I will initially continue my focus on animus-based employer discrimination and assume that the Act affects the decisions of discriminatory employers in the manner set forth in my original Essay. Therefore, the major economic benefit, $b$, provided by Title VII is that it more rapidly eliminates discriminators from the market, thereby eliminating the large psychic costs of discrimination. At the same time, there are three offsetting costs to be considered: 1) the short-run efficiency loss associated with interfering with the preferences of discriminatory employers, $a ; 2)$ the administration costs of the Act, $c$; and 3 ) the adjustment costs associated with driving discriminators from the market, $d$. Subsections (1) through (4) will offer some speculative estimates for variables $a$ through $d$, respectively. Subsection (5) will then evaluate the efficiency of Title VII using these estimates.

1. The Short-run Efficiency Loss Caused by the Act

My original Article demonstrated that Title VII would impose a short-run efficiency cost on discriminators since they would be compelled by law to ignore what for them are the real costs of associating with blacks. I demonstrated that this cost was equal to area $\mathrm{CE}_{2} \mathrm{E}_{1}$ in 
Figure $2 .{ }^{64}$

Figure 2

The Short-Run Supply and Demand for Black Labor Given Employer Discrimination

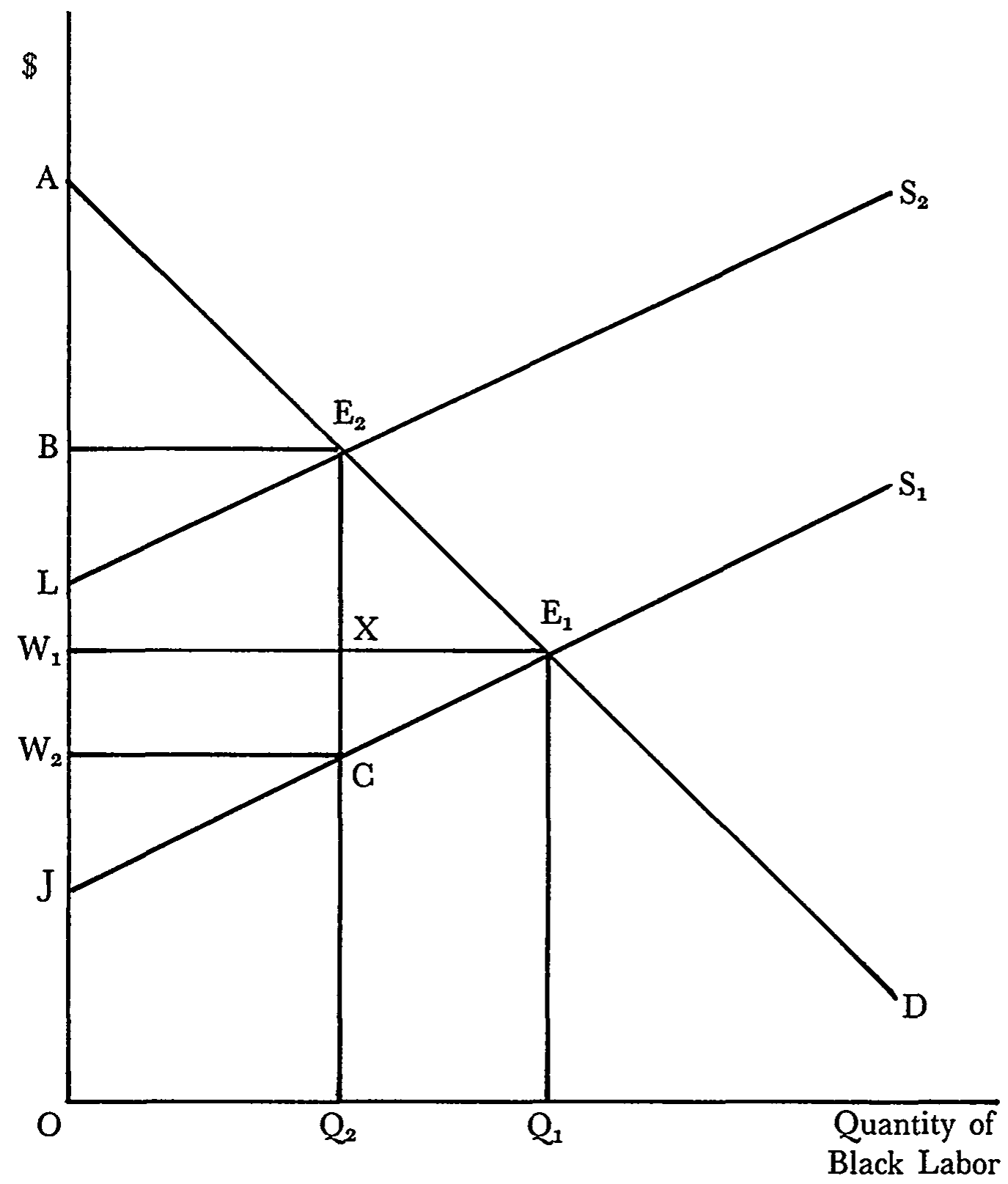

To estimate this area, we need two pieces of information: 1) the increase in black employment that would result from eliminating discrimination - $\mathrm{Q}_{1}-\mathrm{Q}_{2}-$ and 2) the size of the discriminatory "tax" $E_{2}-\mathrm{C}$ - which in subsection (2), below, I estimate to be $10 \%$ of the black wage, $W_{2}$.

B4 See Donohue, supra note 2, at 1429 n.41. 
First, if the $10 \%$ "tax" on black workers were eliminated, black employment would expand: the cost of black labor would fall and the wages received by blacks would rise by a combined total of $10 \%$. It seems reasonable to estimate the drop in the cost of labor to be half the size of the $10 \%$ discriminatory "tax." bor cost would stimulate demand for black labor by $2.5 \%$, assuming an elasticity of demand for black labor of $0.5 .^{66}$ Thus, the increase in black labor hired would be $2.5 \%$ of the 10.7 million black workers, ${ }^{67}$ or approximately 268,700 workers.

Second, $10 \%$ of the mean black salary of $\$ 15,546^{68}$ equals $\$ 1555$. The area of triangle $\mathrm{CE}_{2} \mathrm{E}_{1}$ is then given by $(1 / 2)(268,700)(\$ 1555)=$ $\$ 208.9$ million. This efficiency loss will be incurred each year until all discriminators have been driven from the market, although it will decline continuously as the number of discriminators falls.

65 This assumption implies that, if the discrimination "tax" were eliminated, the benefits from the fall in the total cost to employers-monetary and psychic-of hiring black labor and from the increase in wages paid to black labor would be shared equally by employers and black workers.

${ }^{68}$ Most studies have concluded that the demand for low-wage labor is relatively inelastic. See Brown, Gilroy \& Kohen, The Effect of the Minimum Wage on Employment and Unemployment, 20 J. ECON. LITERATURE 375, 487 (1982); Clark \& Freeman, How Elastic is the Demand for Labor, 20 REv. Econ. \& STATISTICs 509, 518 (1980) (estimating the elasticity of demand for labor at 0.4 or 0.5 ).

67 Total U.S. civilian employment equalled 109.6 million in July of 1986.1987 ECON. REP. OF THE President, at 282. Of this number, $9.8 \%$ were black. BuREAU of the Gensus, U.S. Dept. of Commerce, 1987 Statistical Abstract of the UNITED STATES 385. This calculation provides a figure of 10.7 million black workers.

The number of black full-time workers in 1986 was 8,654,000. See BuREAU of Labor Statistics, U.S. Dept. OF Labor, Employment and Earnings 214 (Jan. 1987).

${ }^{68}$ I estimate the total earnings of the 10.7 million full-time and part-time black employees to be roughly $\$ 167.1$ billion. These figures are obtained as follows: Total wages and salaries paid in 1986 were roughly $\$ 2.07$ trillion. 1987 ECON. REP. OF THE PREsident, at 270 . Of the total male work force $8.8 \%$ is black and $11.1 \%$ of the total female work force is black. Bureau of the Census, U.S. Dep'T of Commerce, supra note 67 , at 378 . Furthermore, black workers on average earn roughly $70 \%$ of nonblack male workers. Cain, supra note 33, at 701 ("the ratios of black-to-white and Hispanic-to-white incomes tend to be around 0.6 or 0.7 "); Smith \& Welch, Race and Poverty: A Forty-Year Record, 77 Am. Econ. Rev. 152 (1987) (Papers and Proceedings) (estimating the black-white wage ratio for men at 0.73 in 1980). I calculate mean black wage as follows: Extrapolating from the 1985 figures, I estimate that there are about 55.5 million nonblack male workers, about 10.7 million black workers, and 43.3 million nonblack female workers, each of whom earns approximately $70 \%$ of the wage of a nonblack male worker. If $W$ is the annual wage of a nonblack male worker, then $55.5(\mathrm{~W})+(10.7+43.3)(0.7)(\mathrm{W})=\$ 2,070,000 . \mathrm{W}=\$ 22,209$, and the average black wage $=\$ 15,546$. Therefore, in 1986 blacks received approximately $8.1 \%$ of the total wage bill, or $\$ 167.1$ billion. 


\section{The Benefits Generated by the Act}

In order to provide some estimate of the benefits associated with the eradication of discrimination, it may be helpful to begin by examining the extreme case in which Title VII succeeded in immediately erasing all discrimination against blacks. In this case, the gain from the Act would simply be the social cost previously imposed by discrimination in employment. In my paper, I analogized this cost to the cost of a tax on black labor in which the revenues were simply discarded. Where the tax revenues are wasted, the cost of the tax would be the revenues themselves plus any associated dead weight efficiency loss. Similarly, as I showed in Figure 2 of my paper, the social cost of employment discrimination against blacks includes the discriminatory "tax" imposed on black labor plus the associated dead weight efficiency loss, which is equal in size to the $\$ 208.9$ million cost estimated in subsection (1). ${ }^{69}$ Therefore, we need only estimate the discriminatory "tax," depicted as $\mathrm{W}_{2} \mathrm{BE}_{2} \mathrm{C}$ in Figure $2 .{ }^{70}$ This requires an estimate of the size of the "tax" - B- $\mathrm{W}_{2}$ - measured as a percentage of the discriminatory wage, $W_{2}$. In Subsection (1), I assumed that the percentage "tax" is twice the size of the percentage increase in the black wage-from $\mathrm{W}_{2}$ to $\mathrm{W}_{1}$-that would occur if discrimination against blacks were eliminated. ${ }^{71}$ Therefore, we must speculate on how much black wages would rise in the absence of racial discrimination in employment. If this percentage increase were $5 \%$, then the discrimination "tax" would be about $\$ 5.6$ billion; if the increase were $10 \%$, then "tax" would rise to $\$ 11.1$ billion. ${ }^{22}$ To be conservative, I will employ the smaller figure.

${ }^{69}$ The total loss caused by the racial discrimination is given by area $\mathrm{W}_{2} \mathrm{BE}_{2} \mathrm{E}_{1} \mathrm{C}$. See Donohue, supra note 2, at 1429 nn.41-42. Area $\mathrm{W}_{2} \mathrm{BE}_{2} \mathrm{C}$ represents the psychic cost to employers of hiring those blacks they would have hired absent Title VII, which is analogous to the wasted tax revenue. Area $\mathrm{CE}_{2} \mathrm{E}_{1}$ represents the dead weight loss stemming from the reduced hiring of blacks, which 1 estimated to be $\$ 208.9$ million.

${ }^{70}$ There is one additional complication: Figure 2 is drawn to reflect a situation in which all employers are initially racial discriminators. Therefore, the amount of the "tax" per black worker multiplied by the number of black workers yields the area of rectangle $\mathrm{W}_{2} \mathrm{BE}_{2} \mathrm{C}$. In Subsection (3), however, I posit that only half of the employers are discriminators. Therefore, the discriminatory "tax" will only be levied by half of the employers. Because the market will then tend to shift black employment away from the discriminators, I will assume that only one-third of black workers will be employed by discriminators. In this event, the elimination of the discriminatory "tax" will only generate one-third of the benefit suggested by the area $\mathrm{W}_{2} \mathrm{BE}_{2} \mathrm{C}$.

71 If the demand for black labor were perfectly elastic, then these two percentages would be identical. The more inelastic is the demand for black labor, ceteris paribus, the greater the difference in these percentages. I assumed in subsection (1) that the demand for black labor is 0.5 .

${ }^{72}$ If one were estimating the entire area $\mathrm{W}_{2} \mathrm{BE}_{2} \mathrm{C}$, then for an $\mathrm{X} \%$ increase in black wages from eliminating discrimination, the estimated discrimination "tax" would be $2 \mathrm{X} \%$ of $\$ 167.1$ billion. Since we must multiply this number by one-third to reflect 
Adding the efficiency loss of $\$ 208.9$ million to the discriminatory "tax" of $\$ 5.6$ billion yields a total cost of discrimination of $\$ 5.8$ billion. ${ }^{73}$ Because Title VII did not immediately drive out all discriminators, the expected yearly benefit from the Act is less than the full $\$ 5.8$ billion estimate. ${ }^{74} \mathrm{~A}$ critical assumption, then, concerns the relative efficiency of the Act versus the free market in eliminating discriminators. My base case assumes that all firms would be driven from the market in 20 years with or without the Act, but that in the first two years after passage Title VII causes a boost in eliminating some discriminators that would have otherwise remained in business for an average of 10 years. If in the first year the passage of the Act succeeded in driving out $\mathrm{X} \%$ of the initial pool of discriminators and only $\mathrm{Y} \%$ would have been driven out without the legislation, then the benefit from the Act would have been $(\mathrm{X}-\mathrm{Y}) \%$ of $\$ 5.8$ billion. Here I will assume that $(\mathrm{X}-\mathrm{Y})=$ 10. This implies that for each year until these discriminators would otherwise have been driven from the market-which I estimate to be ten years-the Act generates benefits of $\$ 578$ million. Moreover, in successive years if $\mathrm{X}-\mathrm{Y}>0$, then a new cohort of discriminating firms will be driven from the market by the Act, adding an additional round of yearly benefits. For my base case, I assume that $X-Y=5$ in the second year. As Table 1 shows, I examine three other cases: 1) when the Act does not increase the number of firms driven out; 2) when the Act only drives out additional firms in the first year; and, 3) when $\mathrm{X}$ $=5 \%$ for 20 years and $\mathrm{Y}=2.5 \%$ for 40 years.

only those black workers employed by discriminatory employers, the "tax" associated at $\mathrm{X}=5 \%$ is given by $(1 / 3)(.10)(\$ 167.1$ billion), or $\$ 5.6$ billion; at $\mathrm{X}=10 \%$, the tax is given by $(1 / 3)(.20)$ ( $\$ 167.1$ billion), or $\$ 11.1$ billion.

73 The relative sizes of the efficiency loss and the discriminatory "tax" reflects a general truth in welfare economics: social cost rectangles are far larger than dead weight triangles. Perhaps the first dramatic illustration of this fact came in evaluating the social cost of monopoly. Harberger had estimated the dead weight loss from monopoly at a very small amount because he only focussed on the dead weight triangle analogous to my area $\mathrm{CE}_{2} \mathrm{E}_{1}$. See Harberger, Monopoly and Resource Allocation, $44 \mathrm{Am}$. ECON. Rev. 77, 86 (1954). It was Judge Posner who then showed that, if monopolists competed for monopoly profits, they would transfer some or all of these profits into social costs-analogous to my discriminatory "tax." As a result, the estimate of the cost of monopoly was substantially elevated. See Posner, The Social Costs of Monopoly and Regulation, 83 J. Pol. Econ. 807, 815-16 (1975).

${ }^{74}$ In Figure 3 of my original Essay, I showed that the time paths of social welfare would be different with and without Title VII. If the early losses imposed by the Act were offset by the later gains-or in the terminology of that Figure, if $b>a$ - then the Act would be efficient. While my $\$ 5.8$ billion estimate of the total cost of discrimination was attempting to approximate $\mathrm{SW}_{1}-\mathrm{SW}_{2}$, one can see from Figure 3 that this difference is greater than the benefit from Title VII in any single year, as long as some of the discriminators are being driven out via pure market forces. 


\section{The Administration Costs of Title VII}

Our analysis requires an estimate of the administration costs generated by Title VII's proscription against discrimination on the basis of race. If we start with Judge Posner's figure of 9000 cases as a rough estimate of the annual number of employment discrimination cases filed in federal court, it might be reasonable to assume that possibly 6000 of these cases are Title VII cases brought by blacks. ${ }^{75}$ If each Title VII case filed in federal court consumed $\$ 12.67$ thousand $^{76}$ in resources, then the social cost of litigated cases would equal about $\$ 76$ million. Perhaps twice as many cases are pursued and settled out of court at a cost in terms of investigation and negotiation expense $\mathrm{e}^{77}$ of $\$ 2$ thousand per case, thereby adding an additional $\$ 24$ million. Therefore, the estimated costs of litigated and nonlitigated cases are $\$ 100$ million. To this we must add any costs incurred by employers in undertaking cosmetic efforts that avoid litigation, without furthering the goal of reduced discrimination. ${ }^{78} \mathrm{I}$ add another $\$ 100$ million for this factor. After adding the budget of the Equal Employment Opportunity Commission ("EEOC"), ${ }^{79}$ administration costs rise to roughly $\$ 300$ million. As with

75 Judge Posner's figure of 9000 represents all cases that are filed in the federal courts and coded as employment discrimination cases by the Administrative Office of the U.S. Courts. I am currently investigating this information to determine what percentage of these cases are Title VII cases brought by blacks. At this point I do not have the results from this study, so I chose the two-thirds figure as a rough approximation. This would imply that only one-third of all cases are brought by nonblacks alleging discrimination on the basis of sex, race, religion, handicap, and age. In making this and succeeding estimates, I have tried to be conservative, relative to the argument that $I$ espouse.

${ }^{78}$ The $\$ 12.67$ thousand figure represents an estimate of the resources consumed by the plaintiffs, defendants, and the judicial system in dealing with all filed Title VII cases. My own analysis of a data tape provided by the Administrative Office of the United States Courts has indicated that $83 \%$ of all employment discrimination cases brought in the federal courts terminate before trial. Accordingly, the legal and judicial resources expended on such cases are relatively small. Using data on federal employment discrimination cases extracted from the Civil Litigation Research Project for me by Herbert Kritzer, whose generous assistance I gratefully acknowledge, I estimate the mean legal fees for plaintiffs to be $\$ 1244$ and for defendants to be $\$ 9378$, expressed in 1986 dollars. To this combined total of $\$ 10,623, I$ add roughly $\$ 2000$ in judicial costs, which yields the $\$ 12.67$ thousand figure. See generally Trubek, Sarat; Felstiner, Kritzer \& Grossman, The Costs of Ordinary Litigation, 31 UCLA L. REv. 72 (1983) (reporting and analyzing results of a national empirical study of the costs of litigation in the United States).

27 I identify the investigation and negotiation expense to be the major transaction cost. This figure does not include the sum that is redistributed from the employer to the employee since simple wealth redistribution imposes no social cost.

${ }^{78}$ Note that the cosmetic efforts could be taken either by nondiscriminators hoping to avoid baseless litigation or by discriminators seeking to continue their unlawful conduct.

${ }^{79}$ The fiscal year 1983 budget for the EEOG was $\$ 146$ million. 18 EEOG ANN. 
the cost of overriding the preferences of discriminatory employers, $a$, this cost should decline each year as the number of discriminators falls. In all cases, I assume that discriminators are eliminated from the market in 20 years under Title VII. Therefore, I consider two cases: 1) where administration costs fall to zero when all discrimination has been eliminated, and 2) where administration costs remain constant at $\$ 300$ million annually forever.

\section{The Increased Adjustment Costs Imposed by Title VII}

In the text, I argued that the only additional adjustment burden imposed by the Act in rapidly eliminating discriminators is caused by the fact that these adjustment costs are borne earlier-and are thus larger in present value terms-under Title VII. If the adjustment cost, $d$, occurs immediately under Title VII, but would occur $T$ years later in the laissez-faire case, then the incremental cost imposed by Title VII is given by:

$$
\text { (2) } d-\left[d /(1+r)^{\mathrm{T}}\right] \text {, }
$$

where $r$ is the real interest rate. In order to estimate this quantity, we therefore need to estimate $d, r$, and $T$. I find $d$ to be difficult to approximate. My approach is as follows: I need to estimate: 1) the number of firms that are prematurely driven from the market, vis-à-vis the laissez-faire case; and 2) the average adjustment cost for each episode. I previously assumed that, in the first year under Title VII, an additional $10 \%$ of the discriminatory firms would be forced to exit. If we assume that half the roughly 100,000 major private employers ${ }^{80}$ are discriminators, then 5000 firms are assumed to be driven out by the Act. ${ }^{81}$ Assuming that each case expends $\$ 200$ thousand in resources, then the cost would be $\$ 1$ billion.

I also choose $r$ to be $10 \%$ and assume that the firms driven out in the first year would have been driven out ten years later without Title VII. ${ }^{82}$ Thus, $T=10$. Substituting these values into Equation (2)

REP. 53, 53 (1984). If we adhere to our assumption that two-thirds of the employment discrimination cases apply to blacks, then this element increases the administration casts by about $\$ 100$ million.

${ }^{80}$ I define a private firm to be a "major employer" if it has at least 100 employees. In 1984, there were 109,021 firms in this category. U.S. BUREAU OF THE CENSUS, County Business Patterns 3 (1984).

${ }^{81}$ In fact, in the last 15 years, there have only been about 90,000 employment discrimination actions brought in the federal court-many of them filed against government agencies-so, clearly, many major employers have never been sued for violating Title VII. Moreover, if we adhere to the previous assumption that two-thirds of these cases allege racial discrimination against blacks, then only 60,000 suits have been filed, many of which could be filed against repeat offenders and governmental entities.

${ }_{82}$ The greater the amount of time that Title VII speeds up the demise of the 
yields:

(3) 1 billion $-\left[1\right.$ billion $\left./(1+.1)^{10}\right]=\$ 614$ million.

Note that this cost is incurred once for each cohort of discriminatory firms driven from the market earlier than they would have been had the Act not been passed. Thus, in my base case, where $5 \%$ of the discriminators are driven out in the second year, there will be an additional cost of $\$ 307$ million. ${ }^{83}$ Therefore, one would expect the number to decline to zero as the number of discriminators remaining falls to zero.

\section{The Final Verdict}

Figure A depicts the four costs and benefits that we have just

Figure A:

COSTS AND BENEFITS OF TITLE VII

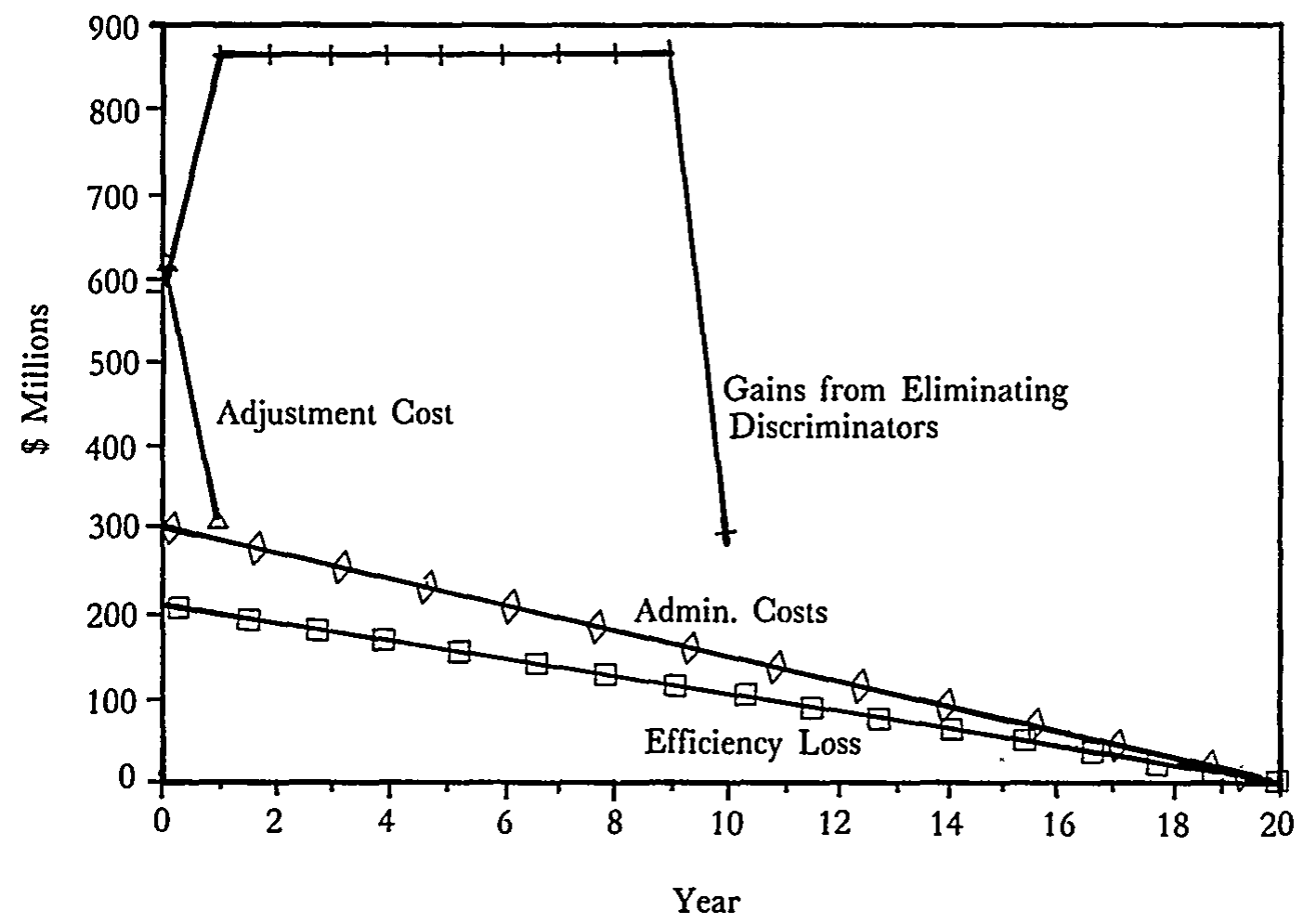

discriminators, the faster expense $d$ is incurred, and thus the more costly the Act becomes. On the other hand, faster elimination of discriminators increases the benefits from the Act. Similarly, a higher real interest rate elevates the additional adjustment burden of Title VII, but it diminishes the stream of other future costs and benefits. The relative magnitudes of costs and benefits were not changed greatly when I used a $5 \%$ discount rate.

${ }^{83}$ Table 1 also presents the case in which the Act drives out all discriminators in 20 years. In this case, the Act eliminates an additional $2.5 \%$ of the discriminators for each of the first 20 years, imposing an adjustment cost of $\$ 144$ million per year, or a net present value of $\$ 1230$. 
estimated for the base case. The figure reveals that by driving out 5000 discriminators in the first year that would have otherwise remained in operation for ten years, the Act would generate yearly benefits of $\$ 578$ million for years one to ten, and by driving out 2500 more in the second year adds additional benefits, $b$, of $\$ 289$ million from years two to eleven. ${ }^{84}$ At the same time, the demise of these firms imposes a one-shot $\$ 614$ million adjustment cost in year one and a $\$ 307$ million cost in year two- $d$. Moreover, the Act imposes two other costs: the dead weight efficiency loss- $a$-that starts at $\$ 208.9$ million per year and declines to zero in year twenty, and the administration costs-c-starting at $\$ 300$ million and declining to zero in year twenty. ${ }^{85}$

In order to assess the efficiency of Title VII under our base set of assumptions, I then discounted the future costs and benefits using a $10 \%$ rate. Reducing these areas to net present values, we find that the benefits of the Act equal $\$ 5165$ million, and the costs $a, c$, and $d$ are $\$ 1200$ million, $\$ 1723$ million, and $\$ 894$ million-or a total cost of $\$ 3816$ million. Based on these estimates of the costs and benefits of the Act, I find that Title VII yields a net gain of $\$ 1349$ million if the Becker model is correct and employers comply with the Act.

Alternatively, if one assumes that the administration costs of the Act continue forever, even after discriminators have been driven from the market, then the net benefits of the Act fall to $\$ 72$ million. ${ }^{86}$ Certainly, if it is fair to assume that a significant number of discriminators will be driven from the market by the Act, the overall impression conveyed by Table 1 is that Title VII generates modest positive efficiency gains. Accordingly, it looks as if Title VII is efficient under the arguments made in my original Essay.

\section{B. Statistical Discrimination}

If all potential employees were white, then race would not provide

84 Thus, the gains from eliminating discriminators are shown to be $\$ 578$ million in the first year, $\$ 867$ million in years two to ten, and $\$ 289$ million in year eleven.

8s Expressed algebraically, the condition for the efficiency of Title VII would be:

$$
\sum_{t}\left\{\frac{\left(b_{t}-a_{t}-c_{t}\right)}{(1+r)^{t}}-\left[1-\frac{1}{(1+r)^{T}}\right] d_{t}\right\}>0
$$

where $T=$ the number of years from the time $d$ is incurred under Title VII until when it would have been incurred had the Act not passed.

${ }_{88}$ The assumption that the administration costs continue at $\$ 300$ million per year forever increases this estimated cost from the $\$ 1723$ million figure given in the text to $\$ 3000$ million, thereby raising the total estimated cost from $\$ 3816$ million to $\$ 5093$ million. 
any useful information to employers. Therefore, if we wish to assess the benefits that it does provide, we need only examine the potential black work force of 10.7 million workers. Now, presumably, race provides potentially useful information to an employer only at the time of hiring a worker; once the worker has been employed for a while, the employer would be able to form more precise judgments than those based on a crude racial indicator. Therefore, race should provide information only to an employer hiring a new worker. While I am not persuaded that there are substantial differences between blacks and whites after one has taken into account easily measured traits such as education and academic performance, for this analysis I will accept Judge Posner's argument that such is the case.

If 3 million blacks apply for 3 jobs each every year, then there will be 9 million instances in which race might be a factor providing information to an employer. But while on average race might provide useful information, it is clearly not a precise measure. With some investment of time, one would expect that the useful information conveyed by race could be obtained in some other fashion. If it could be purchased at the cost of $\$ 10$ per instance, then the added cost to the employer from testing would be $\$ 90$ million per year. On the other hand, because race is a crude measure, its use will generate errors. For example, high productivity blacks will be rejected in favor of average productivity white workers. If such blacks happened to be only $1 \%$ more productive than the lower productivity whites who were hired in their place, then the loss to employers would be roughly $\$ 222$ per year. ${ }^{87}$ Even if only the top $10 \%$ of black workers-300,000 applicants-were superior to average white workers, then the employer would sacrifice $\$ 66.6$ million in lost productivity by using race as an informational device to evaluate these black workers. Therefore, the net benefit to employers of statistical discrimination might be assessed at $\$ 23.4$ million per year. ${ }^{88}$ Using other plausible values for the costs associated with statistical discrimination might well suggest that this practice is not profitable for employers. $^{89}$

Moreover, banning statistical discrimination encourages blacks to invest in their own human capital, since they will be more fully re-

${ }^{87}$ The mean earnings of nonblack male workers in 1986 were $\$ 22,209$. See supra note 68. One percent of this figure would be $\$ 222$.

${ }^{88}$ The $\$ 90$ million savings in information costs is offset against the $\$ 66.6$ million loss in productivity.

s9 Presumably, if statistical discrimination were not even profitable for employers, few employers would engage in this practice. In that event, the ability of statistical discrimination to explain the perceived black-white earnings would be seriously in doubt. 
warded for their individual strengths and held more accountable for their individual shortcomings. In addition, the passage of Title VII itself will encourage blacks to invest more in their human capital more generally, causing a convergence in skills between blacks and whites. It is hard to put an estimate on these considerations, but if the three million job searchers mentioned above were induced by the banning of discrimination to invest $\$ 100$-in time or money-in greater education or training, one might expect at least a $13 \%$ return on this investment. ${ }^{90}$ The benefit of such a return for a 40 -year period, discounted at $10 \%$, would be $\$ 127.13$. In this event, the cost imposed by statistical discrimination each year is $\$ 27.13$ per worker times 3 million workers, or $\$ 81.4$ million. On the other hand, if in succeeding years the investments were only undertaken by the new entrants to the black labor force-perhaps about 300,000 workers per year-the future stream of benefits would fall to roughly $\$ 8.14$ million. Depending on one's precise estimates of this pattern, statistical discrimination evaluated on its own may be either efficient or inefficient..$^{91}$

In Table 1, I adjust the previous estimates of Title VII under two different assumptions concerning the effect of banning statistical discrimination. First, I assume that statistical discrimination yielded benefits to employers of $\$ 23.4$ million per year from decreased informational costs, but that it imposed burdens on workers by distorting their human capital investment decisions. I assume that the total benefit from banning statistical discrimination in terms of added investment in human capital would equal $\$ 81.4$ million in the first year and $\$ 8.14$ million per year thereafter. These adjustments reduce the net benefits of the Act in present value terms by about $\$ 86$ million. Second, I also present figures based on the assumption that banning statistical discrimination has no effect on the investment decisions of workers. In this

${ }^{80}$ Estimates of the monetary returns to human capital investment range from $8 \%$ to around $30 \%$, with the latter figure representing the higher, nonlinear returns to investments in college education. Since there are also nonpecuniary benefits associated with "better" jobs, my estimate of a return on human capital investment that is only 3 percentage points above the discount rate seems conservative. See Willis, Wage Determinants: $A$ Survey and Reinterpretation of Human Capital Earnings, in 1 HANDBOOK OF LABOR ECONOMICS 525, 536 (1986) (estimated rates of return on schooling are "higher than the real interest rate"). I benefited from discussions with Joseph Altonji on this general subject.

91 If it were to appear that statistical discrimination imposed costs on workers that exceeded the benefits conferred on employers, then one would think that workers and employers would have a mutual incentive to eradicate statistical discrimination through some Pareto optimal agreement. But transactions costs and the inability to harness by contractual agreement a portion of a worker's future stream of earnings might explain why such agreements are not voluntarily reached, even when a governmental proscription of statistical discrimination would be efficient. 
case, the only effect of banning this form of discrimination is to impose the information burden on employers, which reduces the net benefits of the Act by $\$ 234$ million. $^{92}$ In the base case, these changes do not affect the finding of the efficiency of the Act unless one also assumes that the administration costs of $\$ 300$ million per year will also continue forever.

92 The amount $\$ 23.4$ million per year forever implies a net present value of $23.4 / .1=\$ 234$ million. 
HeinOnline -- 136 U. Pa. L. Rev. 552 1987-1988 